\title{
PENGARUH BUDAYA ORGANISASI TERHADAP KINERJA KARYAWAN BAGIAN ADMINISTRASI UMUM PADA PT PLN (PERSERO) AREA BANDUNG
}

\author{
Iis Dewi Fitriani \\ Budi Sadarman \\ STIE Muhammadiyah Bandung \\ Jl. Karapitan No.143 Bandung
}

\begin{abstract}
Abstrak
Permasalahan peningkatan kinerja erat kaitannya dengan permasalahan bagaimana memotivasi karyawan, bagaimana pengawasan dilakukan, dan bagaimana cara mengembangkan budaya organisasi yang efektif serta bagaimana menciptakan lingkungan kerja yang nyaman dan kondusif, agar karyawan dapat dan mau bekerja secara optimal, sehingga dapat mendukung pencapaian tujuan perusahaan. Budaya organisasi juga berkaitan erat dengan pemberdayaan karyawan (employee empowerment) di suatu perusahaan, setiap perusahaan mengharapkan terciptanya rasa kekeluargaan antara anggota yang satu dengan yang lain dan akhirnya dapat berpengaruh pada peningkatan kinerja secara optimal di dalam perusahaan tersebut. Ada beberapa komponen Budaya Organisasi yang diterapkan pada PT PLN (Persero).

Metode penelitian yang di gunakan pada penelitian ini adalah metode deskriptif dengan pendekatan kuantitatif, menurut Sugiyono (2008:147) metode deskriptif adalah statistik yang digunakan untuk menganalisis data dengan cara mendeskripsikan atau menggambarkan data yang telah terkumpul sebagaimana adanya tanpa bermaksud membuat kesimpulan yang berlaku untuk umum atau generalisasi. Berdasarkan pengertian tersebut, maka dapat disimpulkan metode deskriptif bertujuan menggambarkan benar tidaknya fakta - fakta yang ada serta menjelaskan tentang pengaruh antara varibel yang diselidiki dengan cara mengumpulkan data.

hasil uji validitas dan uji reliabilitas butir variabel Budaya Organisasi dan butir variabel Kinerja Karyawan di atas menunjukan bahwa terdapat tiga butir pernyataan dinyatakan tidak valid yaitu pada pertanyaan pernyataan nomor Y8, Y12, dan Y15 sehingga butir - butir pertanyaan pernyataan yang tidak valid akan dikeluarkan dari analisis selanjutnya karena memiliki nilai validitas kurang dari 0,30 validitas dinyatakan valid apabila nilai butir tersebut lebih besar dari 0,30 sedangkan uji reliabilitas dinyatakan reliable karena baik variabel $\mathrm{X}$ budaya organisasi maupun variabel Y kinerja karyawan memiliki nilai lebih besar dari 0,60.

Hasil penelitian ini menjelaskan bahwa besarnya nilai korelasi sebesar 0,592 dan dijelaskan besarnya presentasi pengaruh Variabel Independen terhadap Variabel Dependen. Dari output tersebut diperoleh Koefisien Determinasi (R2) sebesar 59,2\% sedangkan sisanya $40,8 \%$ dipengaruhi oleh variabel lain.
\end{abstract}

Kata kunci : Budaya Organisasi dan Kinerja Karyawan

\section{PENDAHULUAN}

Manajemen sumber daya manusia (MSDM) merupakan manajemen keorganisasian yang memfokuskan diri pada unsur sumber daya manusia. Pada dasarnya di dalam sebuah perusahaan 
sumber daya manusia adalah aset yang paling berharga, manusia selalu ikut aktif berperan dan paling menentukan tercapai tidaknya tujuan perusahaan tersebut karena manusialah yang dapat menggerakan semua sumber daya yang ada. Dengan demikian unsur sumber daya manusia merupakan kunci yang harus dipertahankan dalam suatu perusahaan, sejalan dengan tuntutan yang ada dalam sebuah perusahaan untuk menjawab setiap tantangannya, oleh karena itu, upaya untuk menciptakan sumber daya yang berkualitas merupakan langkah utama pada perusahaan.

Menyadari pentingnya peranan sumber daya manusia tersebut pihak perusahaan telah banyak melakukan kegiatan untuk memberdayakan para karyawan sehingga memiliki kemampuan dan kinerja yang optimal dalam upaya pencapaian tujuan perusahaan. Adapun suatu perusahaan yang telah menjalankan hal tersebut memiliki ciri-ciri perubahan yang bersifat mendasar, strategis, dan menyeluruh sehingga tujuan yang telah di tetapkan dapat terlaksana.

Pada dasarnya ciri - ciri tersebut sesuai dengan tujuan dan manfaat dalam organisasi karena di temukan hubungan kuat yang saling mempengaruhi satu sama lain antara budaya organisasi terhadap kinerja karyawan pada perusahaan. Secara umum dapat diartikan organisasi adalah sebagai suatu himpunan / kumpulan dua orang atau lebih manusia yang terikat dalam suatu sisitem dan melakukan kerjasama yang terstuktur dalam mencapai tujuan bersama, perkembangan dan kemajuan suatu organisasi tidak bisa dikesampingkan dengan peranan format dan konsep budaya yang terapkan dalam suatu organisasi Karena budaya adalah cerminan cara bersikap, berfikir, berbuat yang dianut oleh karyawan dan itu telah menjadi kebiasaan yang berlaku lama.

Menurut Irham Fahmi (2013:47) Budaya organisasi adalah suatu kebiasaan yang telah berlangsung lama dan dipakai serta diterapkan dalam kehidupan aktivitas kerja sebagai salah satu pendorong untuk meningkatkan kualitas kerja para karyawan dan manager perusahaan. Budaya yang ada pada suatu organisasi akan mempengaruhi cara pekerjaan yang di lakukan dan cara pekerja berperilaku sebab para pekerja memiliki cara pandang yang sama dalam melaksanakan aktivitas pekerja, budaya organisasi juga memiliki dampak Terhadap efisiensi dan efektivitas perusahaan.

Budaya organisasi juga berkaitan erat dengan pemberdayaan karyawan (employee empowerment) di suatu perusahaan, setiap perusahaan mengharapkan terciptanya rasa kekeluargaan antara anggota yang satu dengan yang lain dan akhirnya dapat berpengaruh pada peningkatan kinerja secara optimal di dalam perusahaan tersebut. Ada beberapa komponen Budaya Organisasi yang diterapkan pada PT PLN (Persero) Hal itu bisa dilihat dari tabel di bawah ini:

Sebagai perusahaan tunggal yang memasok listrik ke seluruh Indonesia tentunya harus memperhatikan budaya organisasi yang ada pada perusahaan tersebut, karena PT PLN (Persero) adalah perusahaan negara yang menjadi sorotan dari berbagai pihak mengenai budaya organisasi dan kinerja karyawannya. Budaya organisasi pada PT PLN (Persero) senantiasa membudayakan kebiasaan baik seperti perlunya adaptasi pada lingkungan eksternal dengan cepat dan efektif secara berkesinambungan yang senantiasa menjaga keutuhan internal. Suatu budaya yang dipakai dan diterapkan dalam kehidupan selama periode waktu yang lama akan mempengaruhi pola pembentukan dari suatu organisasi, setiap perusahaan pasti mengharapkan seluruh karyawannya mentaati pedoman perilaku yang ada seperti taat aturan, bertanggung jawab, berbagi pengetahuan, proaktif, 
saling membantu, dan berinovasi. Ketika peneliti melakukan pengamatan langsung pada bagian Administrasi Umum di PT PLN Area Bandung serta melakukan wawancara mengenai bagaimana aplikasi pedoman perilaku yang ada pada perusahaan tersebut. Peneliti mendapatkan informasi bahwa masih banyak karyawan yang kurang memiliki tenggang rasa antara sesama dan terdapat beberapa karyawan yang masih sering terlambat masuk kerja dengan alasan yang kurang jelas. Hal itu bisa di lihat dari tabel di bawah

ini.

Tabel 1.Rekapitulasi Absensi Karyawan bagian Administrasi Umum Pada PT PLN (Persero) Area Bandung Tahun 2013-2015

\begin{tabular}{|c|c|c|c|c|c|c|}
\hline \multirow[b]{2}{*}{ Bulan } & \multicolumn{2}{|c|}{2013} & \multicolumn{2}{|c|}{2014} & \multicolumn{2}{|c|}{2015} \\
\hline & $\begin{array}{c}\text { Terlambat } \\
\text { masuk } \\
\text { lebih dari } 30 \\
\text { menit } \\
\end{array}$ & $\begin{array}{c}\text { Jumla } \\
\mathbf{h} \\
\text { orang }\end{array}$ & $\begin{array}{c}\text { Terlambat } \\
\text { masuk } \\
\text { lebih dari } \\
\mathbf{3 0} \text { menit } \\
\end{array}$ & $\begin{array}{c}\text { Jumla } \\
\mathbf{h} \\
\text { orang }\end{array}$ & $\begin{array}{c}\text { Terlambat } \\
\text { masuk } \\
\text { lebih dari } 30 \\
\text { menit } \\
\end{array}$ & $\begin{array}{c}\text { Jumla } \\
\mathbf{h} \\
\text { orang }\end{array}$ \\
\hline Januari & 5 kali & 4 & - & - & 12 kali & 8 \\
\hline Februari & 2 kali & 1 & - & - & 28 kali & 10 \\
\hline Maret & 11 kali & 4 & 28 kali & 12 & 8 kali & 7 \\
\hline April & 8 kali & 6 & 20 kali & 11 & 13 kali & 7 \\
\hline Mei & 7 kali & 3 & 24 kali & 8 & 31 kali & 13 \\
\hline Juni & 29 & 11 & 7 kali & 7 & 30 kali & 12 \\
\hline Juli & 7 kali & 3 & 15 kali & 6 & 9 kali & 6 \\
\hline Agustus & 20 kali & 7 & 6 kali & 3 & 30 kali & 7 \\
\hline $\begin{array}{c}\text { Septembe } \\
\mathbf{r}\end{array}$ & 17 kali & 8 & 16 kali & 9 & 13 kali & 8 \\
\hline Oktober & 2 kali & 1 & 8 kali & 4 & 33 kali & 12 \\
\hline $\begin{array}{c}\text { Novembe } \\
\mathbf{r}\end{array}$ & 10 kali & 5 & 11 kali & 6 & 36 kali & 12 \\
\hline Desember & 11 kali & 8 & 7 kali & 4 & 9 kali & 8 \\
\hline Jumlah & 129 kali & & 142 kali & & 252 kali & \\
\hline
\end{tabular}

Sumber : PT.PLN (Persero) Area Bandung

Berdasarkan table 1.2 data absensi bagian Administrasi Umum pada PT PLN (Persero) Area Bandung diatas dapat dilihat bahwa masih ada beberapa karyawan yang menjadikan keterlambatan sebagai budaya sehingga kurang taat akan peraturan yang ada pada perusahaan tepatnya PT PLN Area Bandung. Absensi tersebut dapat berpengaruh pada kinerja kerja para karyawan karena kurangnya rasa tangung jawab dan kurangnya pemanfaatan waktu. Menurut Suwanto dan Donni (2010:196) Kinerja merupakan performance atau unjuk kerja. Kinerja dapat pula diartikan prestasi kerja atau pelaksanaan kerja atau hasil unjuk kerja.

Permasalahan peningkatan kinerja erat kaitannya dengan permasalahan 
bagaimana memotivasi karyawan, bagaimana pengawasan dilakukan, dan bagaimana cara mengembangkan budaya organisasi yang efektif serta bagaimana menciptakan lingkungan kerja yang nyaman dan kondusif, agar karyawan dapat dan mau bekerja secara optimal, sehingga dapat mendukung pencapaian tujuan perusahaan.

Menurut Irham Fahmi (2013:2) Kinerja adalah hasil yang di peroleh oleh suatu organisasi baik organisasi tersebut bersifat profit oriented dan non profit oriented yang di hasilkan selama satu periode waktu. Menurut Amstrong dan Baron (Irham Fahmi, 2013:2) mengatakan kinerja merupakan hasil pekerjaan yang memiliki hubungan kuat dengan tujuan strategis organisasi kepuasan konsumen dan memberikan kontribusi ekonomi.

Kesuksesan sosialisasi budaya organisasi selanjutnya akan berdampak positif pada kinerja kerja karyawan sementara kegagalannya berarti memberi dampak negatif terhadap kinerja kerja karyawan. Budaya organisasi yang kuat dapat menciptakan suasana kerja yang kondusif sehingga kualitas kerja akan tertingkatkan hal itu merupakan kunci keberhasilan bagi suatu organisasi, di mana keberhasilan organisasi menjadi satu indikator kinerja kerja karyawan dalam suatu perusahaan salah satunya pada PT PLN (Persero) bagian Administrasi Umum Area Bandung. Berikut tabel data kinerja pada PT PLN (Persero) bagian Administrasi Umum Area Bandung.

TABEL 2.Data Kinerja Karyawan Bagain Administrasi Umum Pada PT PLN (Persero) Area Bandung

\begin{tabular}{|c|c|c|c|c|c|c|c|c|c|c|}
\hline \multirow{3}{*}{$\begin{array}{l}\mathbf{N} \\
\mathbf{0}\end{array}$} & \multirow{3}{*}{$\begin{array}{c}\text { Prilaku } \\
\text { kerja }\end{array}$} & \multicolumn{9}{|c|}{ Tahun } \\
\hline & & \multicolumn{3}{|c|}{2013} & \multicolumn{3}{|c|}{2014} & \multicolumn{3}{|c|}{2015} \\
\hline & & $\begin{array}{c}\text { Bob } \\
\text { ot }\end{array}$ & $\begin{array}{c}\text { Pencapa } \\
\text { ian \% }\end{array}$ & $\begin{array}{l}K \\
\text { et }\end{array}$ & $\begin{array}{c}\text { bob } \\
\text { ot }\end{array}$ & $\begin{array}{c}\text { Pencapa } \\
\text { ian \% }\end{array}$ & $\begin{array}{l}K \\
\text { et }\end{array}$ & $\begin{array}{c}\text { bob } \\
\text { ot }\end{array}$ & $\begin{array}{c}\text { Pencapa } \\
\text { ian \% }\end{array}$ & $\begin{array}{l}K \\
\text { et }\end{array}$ \\
\hline 1. & $\begin{array}{l}\text { Kedisiplin } \\
\text { an }\end{array}$ & 10 & 88 & M & 10 & 99 & $\mathrm{~B}$ & 10 & 88 & M \\
\hline 2. & $\begin{array}{c}\text { Tanggung } \\
\text { jawab }\end{array}$ & 10 & 93 & $\mathrm{H}$ & 10 & 100 & $\mathrm{~B}$ & 10 & 70 & M \\
\hline 3. & Kerjasama & 10 & 95 & $\mathrm{~B}$ & 10 & 97 & $\mathrm{~B}$ & 10 & 89 & $\mathrm{M}$ \\
\hline 4. & $\begin{array}{l}\text { kepemimp } \\
\text { inan }\end{array}$ & 10 & 92 & $\mathrm{H}$ & 10 & 100 & $\mathrm{~B}$ & 10 & 90 & $\mathrm{H}$ \\
\hline \multicolumn{11}{|c|}{ Hasil kerja } \\
\hline 1. & $\begin{array}{c}\text { Kualitas } \\
\text { kerja }\end{array}$ & 20 & 78 & $\mathrm{M}$ & 20 & 97 & $\mathrm{~B}$ & 20 & 88 & $\mathrm{M}$ \\
\hline 2. & $\begin{array}{c}\text { Kuantitas } \\
\text { Kerja }\end{array}$ & 20 & 78 & $\mathrm{M}$ & 20 & 97 & $\mathrm{~B}$ & 20 & 88 & M \\
\hline 3. & $\begin{array}{l}\text { Keterampi } \\
\text { lan kerja }\end{array}$ & 20 & 78 & M & 20 & 97 & B & 20 & 88 & M \\
\hline & Jumlah & 100 & 602 & - & 100 & 687 & - & 100 & 601 & - \\
\hline & Rata-rata & - & 86 & $\mathrm{M}$ & - & 98,1 & $\mathrm{~B}$ & - & 85,9 & $\mathrm{M}$ \\
\hline
\end{tabular}

Sumber: PT PLN (Persero) Area Bandung 
Kategori Baik (B) $\quad=\geq 95$

Kategori Hati-hati $(\mathrm{H}) \quad=90-94$

Kategori Masalah $(\mathrm{M})=\leq 90$

Berdasarkan data kinerja pada PT PLN (Persero) Area Bandung di atas dapat dilihat bahwa kondisi kinerja tahun 2015 mengalami penurunan dengan memperoleh pencapaian $85.9 \%$ selaras dengan table 1.2 yang telah peneliti sajikan mengenai data absensi keterlambatan karyawan.

Menurut beberapa narasumber yang sempat berdiskusi saat makan siang bersama di kantin dengan peneliti bahwasannya perusahaan selalu menginginkan para karyawan untuk dapat memahami dan mengerjakan berbagai pekerjaan yang ada sehingga para karyawan memiliki kesiapan dan kemampuan jika suatu saat terjadi rolling atau pertukaran tanggung jawab, dapat membantu satu sama lain agar terciptanya tenggang rasa antar karyawan dan tidak bersifat individual sehingga pekerjaan yang sedang dikerjakan akan lebih cepat terselesaikan.

\section{KERANGKA HIPOTESIS}

\section{TEORITIS}

\&

\section{Kinerja Karyawan}

Berdasarkan etimologi kinerja berasal dari kata performance yang berarti prestasi kerja, Kinerja adalah hasil yang di peroleh oleh suatu organisasi baik organisasi tersebut bersifat profit oriented dan non profit oriented yang di hasilkan selama satu periode waktu. Secara lebih tegas Amstrong dan Baron (Irham Fahmi, 2013:2) mengatakan kinerja merupakan hasil pekerjaan yang mempunyai hubungan kuat dengan tujuan strategis organisasi, kepuasan konsumen dan memberikan kontribusi ekonomi.

"Kinerja adalah hasil kerja yang dapat dicapai oleh seseorang atau sekelompok orang dalam suatu organisasi, sesuai dengan wewenang dan tanggungjawab masing - masing, dalam rangka upaya mencapai tujuan organisasi bersangkutan secara legal, tidak melanggar hukum dan sesuai dengan moral dan etika". Prawirosentono (Lijan Poltak Sinambela, 2012:5)

Ada beberapa pengertian kinerja yang dikemukakan beberapa pakar lain dalam Rivai, dan Basri, (Lijan Poltak Sinambela, 2012:7-8) dapat disajikan berikut ini:

a. Kinerja adalah seperangkat hasil yang dicapai dan merujuk pada tindakan pencapaian serta pelaksanaan suatu pekerjaan yang diminta (Stolovitch, Keep: 1992)

b. Kinerja merupakan salah satu kumpulan total dari kerja yang ada pada diri pekerja (Griffin: 1987)

c. Kinerja adalah kesediaan seseorang atau kelompok orang untuk melakukan suatu kegiatan dan menyempurnakannya sesuai dengan tanggungjawabnya dengan hasil seperti yang diharapkan. Jika dikaitkan dengan kinerja sebagai kata benda dimana salah satu entrinya adalah hasil dari suatu pekerjaan pengertian kinerja adalah hasil kerja yang dapat dicapai oleh seseorang atau kelompok orang oleh suatu perusahaan sesuai dengan wewenang dan tanggung jawab masing - masing dalam upaya pencapaian tujuan perusahaan secara legal, tidak melanggar hukum dan tidak bertentangan dengan moral atau etika. (Rivai, Basri, 2005: 15-16)

Anwar Prabu Mangkunegara (2014:9) Kinerja sumber daya manusia (SDM) merupakan istilah yang berasal dari kata job performance atau Actual performance (prestasi kerja atau prestasi sesungguhnya yang di capai seseorang). 
Definisi kinerja karyawan yang di kemukakan Bambang Kusriyanto adalah: "perbandingan hasil yang di capai dengan peran serta tetangga kerja persatuan waktu (lazimnya per jam)".

\section{Faktor - Faktor Yang Mempengaruhi Kinerja Karyawan}

Faktor kinerja karyawan adalah faktor kemampuan (ability) dan faktor motivasi (motivation). Hal yang sesuai dengan pendapat Keith Davis (Anwar Prabu, 2014:13) yang merumuskan bahwa:

$\begin{array}{ccc}\text { Human perpormance } & = & \text { Ability } \\ x & \text { Motivation } & \\ \text { Motivation } & =\text { Attitude } \\ x & \text { Situation } & \\ \text { Ability } & & =\text { Knowledge } \\ x & \text { Skill } & \end{array}$

adalah hasil:

Dengan kata lain, kinerja individu

a. Atribut individu, yang menentukan kapasitas untuk mengerjakan sesuatu. Atribut individu meliputi faktor individu (kemampuan dan keahlian, latar belakang serta demografi) dan faktor psikologis meliputi persepsi, attitude, personality, pembelajaran dan motivasi.

b. Upaya kerja (work effort), yang membentuk untuk mencapai sesuatu.

c. Dukungan organisasi, yang memberikan kesempatan untuk berbuat sesuatu. Dukungan organisasi meliputi sumber daya, kepemimpinan, lingkungan kerja, struktur organisasi dan job design

Menurut A. Dale Timple (Anwar Prabu M, 2014:15) Faktor - faktor kinerja terdiri dari faktor internal dan eksternal. Faktor Internal (disposisional) yaitu faktor yang dihubungkan dengan sifat - sifat seseorang. Misalnya, kinerja seseorang baik karena memiliki kemampuan tinggi dan orang tersebut adalah tipe pekerja keras, sedangkan jika orang tersebut berkinerja buruk itu karena orang tersebut memiliki kemampuan rendah dan tidak memiliki upaya - upaya untuk memperbaiki kemampuannya.

Faktor Eksternal yaitu Faktor faktor yan mempengaruhi kinerja seseorang yang berasal dari lingkungan. Seperti perilaku, sikap, tindakan tindakan rekan kerja, bawahan dan pimpinan, fasilitas kerja, dan iklim organisasi. tanpa mengetahui dan memperhatikan faktor - faktor yang mempengaruhi kinerja karyawan di atas maka kriteria kinerja yang baik pada sebuah perusahaan tidak akan terpenuhi.

\section{Aspek - Aspek Kinerja Karyawan}

Ada beberapa aspek dalam kinerja karyawan menurut Husein Umar (2001:266) mengenai aspek-aspek kinerja sebagai berikut:

a) Mutu pekerjaan, mutu yang harus dihasilkan atau tidak melibatkan perhitungan dari pengeluaran dan proses atau pelaksanaan kegiatan dari karyawan terutama dalam kaitan keluaran (output).

b) Kejujuran karyawan, merupakan ketulusan hati dari seorang pegawai dalam melaksanakan tugasnya dan mampu untuk tidak menyalahgunakan wewenang yang diberikan

c) Inisiatif, kemampuan untuk bertindak tidak bergantung kepada orang lain dan mampu mengembangkan serangkaian kegiatan serta dapat menemukan cara - cara yang baru atau mampu berinovasi.

d) Kehadiran, kewajiban yang harus dilaksanakan oleh karyawan dalam setiap pekerjaan dimana kehadiran merupakan hal utama yang harus dilaksanakan oleh setiap karyawan.

e) Sikap, suatu kesediaan untuk berinteraksi di dalam menghadapi suatu situasi atau keadaan tertentu secara normal. 
f) Kerjasama, kemampuan seorang karyawan untuk bekerja bersama sama dengan orang lain untuk menyelesaikan suatu tugas yang ditentukan, sehingga mencapai daya guna dan hasil guna sebesar besarnya. Kesediaan karyawan dalam berpartisipasi dan bekerjasama dengan karyawan lain secara vertical dan horizontal di dalam maupun di luar pekerjaan sehingga hasil pekerjaan akan meningkat.

g) Keandalan, total dari semuah keahlian yang diperlukan untuk mencapai hasil yang bisa dipertanggungjawabkan.

h) Pengetahuan tentang pekerjaan, pengetahuan yang dimiliki oleh setiap karyawan dalam melaksanakan suatu pekerjaan sehingga dapat berjalan secara efektif dan efisien.

i) Tanggung jawab, suatu kesanggupan dari seorang karyawan dalam menyelesaikan pekerjaan yang dibebankan kepadanya dengan sebaik - baiknya.

j) Pemanfaatan waktu, ketepatan waktu adalah jenis khusus dari pengukuran kuantitatif untuk menentukan ketepatan waktu penyelesaian suatu kegiatan.

\section{Budaya Organisasi}

Menurut Robbins (Deddy Mulyadi 2015:95) budaya organisasi adalah Istilah yang dipakai untuk memuat rangkaian variable-variable perilaku yang mengacu kepada nilai-nilai, kepercayaaankepercayaan, dan prinsip pokok yang berperan sebagai suatu dasar bagi sistem manajemen organisasi. Budaya organisasi juga merupakan teori-teori yang menjelaskan sasaran dan prosedur untuk mencapai tujuan.

Menurut Miller (Deddy Mulyadi, 2015:95) menyebutkan bahwa: Budaya organisasi adalah nilai dan semangat yang mendasar dalam cara mengelola serta mengorganisasikannya. Nilai-nilai itu merupakan keyakinan yang di pegang teguh dan kadang-kadang tidak terungkap. Dengan demikian nilai-nilai dan semangat ini akan mendasari sifat organisasi dalam usaha menjawab tantangan.

Sedangkan menurut Daniel Denison (Deddy Mulyadi, 2015:95) mengatakan bahwa budaya organisasi adalah kekuatan dan potensi yang dimiliki suatu organisasi untuk melakukan koordinasi dan kontrol terhadap perilaku anggota organisasi, sehingga kuatnya suatu budaya organisasi yang baik, akan berpengaruh makin meningkatnya mutu informasi serta koordinasi perilaku.

Menurut Peter F Druicker (Tika, 2012:4) Budaya organisasi adalah pokok penyelesaian masalah - masalah eksternal dan internal yang pelaksanaannya dilakukan secara konsisten oleh suatu kelompok yang kemudian mewariskan kepada anggota - anggota baru sebagai cara yang tepat untuk memahami, memikirkan, dan merasakan terhadap masalah - masalah terkait.

Definisi tentang budaya organisasi diatas sangat beragam berkenan dengan hal tersebut dapat di simpulkan bahwa budaya organisasi merupakan suatu nilai, norma, sikap, perilaku, maupun kepercayaan yang ada didalam organisasi tersebut.

\section{Fungsi Budaya Organisasi}

Didalam suatu organisasi peran budaya dalam mempengaruhi karyawan tampaknya semakin penting karena dilihat Dari pengertian-pengertian budaya organisasi di atas, dalam kehidupan organisasi. Ouchi (Deddy Mulyadi, 2015:97) Dalam kaitan ini menyatakan bahwa "Budaya organisasi berfungsi sebagai sarana untuk mempersatukan kegiatan para anggota organisasi, yang terdiri dari sekumpulan individu dengan latar belakang kebudayaan yang khas.

Pascale (Deddy Mulyadi, 2015:97) menegaskan bahwa budaya organisasi 
pada dasarnya berfungsi untuk mengajarkan kepada para anggotanya, bagaimana mereka harus berkomunikasi dan berhubungan dalam menyelesaikan masalah. Ada 4 fungsi budaya organisasi, yaitu:

1. Menentukan peran yang membedakan organisasi yang satu dengan lainnya;

2. Menimbulkan dan merangsang perasaan ikut memiliki identitas bagi para karyawan;

3. Mengutamakan tercapainya tujuan bersama di bandingkan sekedar kesenangan individu;

4. Menjaga stabilitas (kemampuan) social organisasi

Fungsi budaya organisasi menurut Chatab (Deddy Mulyadi, 2015:118) sebagai berikut:

1. Identitas, yang merupakan cirri atau karakter organisasi.

2. Socialcohesion atau pengikat/pemersatu seperti bahasa sunda yang bergaul dengan orang sunda, sama hobi olah-raganya.

3. Sources, misalnya insfirasi

4. Sumber penggerak dan pola prilaku.

5. Kemampuan meningkatkan nilai tambah

6. Pengganti formalisasi

7. Mekanisme adaptasi terhadap perubahaan seperti adanya rumah susun.

8. Orientasinya seperti konteks tinggi (kata-kata menjadi jaminan), konteks rendah (tertulis menjadi penting) dan konteks rendah (karena diikuti tertulis dengan sub-konteks tinggi (perintah lisan).

Robbins (Deddy Mulyadi, 2015:119) menyebutkan bebarapa fungsi budaya organisasi:

1. Budaya mempunyai suatu peran pembeda. Hal itu berarti bahwa budaya kerja menciptakan pembedaan yang jelas antara satu organisasi dengan yang lain.
2. Budaya organisasi membawa suatu rasa identitas bagi anggota-anggota organisasi

3. Budaya organisasi mempermudah timbul pertumbuhan komitmen pada sesuatu yang lebih luas dari pada kepentingan diri individual

4. Budaya organisasi itu meningkatkan kemantapan sistem sosial.

\section{Karakteristik Budaya Organisasi}

O'Reily dan Jehn (Deddy Mulyadi, 2015:121-122) menyebutkan terdapat tujuh karakteristrik utama budaya organisasi:

1. Innovation and risktaking (Inovasi dan mengambil resiko), Yakni derajat sejauh mana pekerjaan didorong untuk inovatif dan berani mengambil resiko. Tingkat karyawan dalam menciptakan inovasi dan peluang untuk berkreativitas.

2. Attention to detail (Perhatian kepada detail). Yakni derajat sejauh mana para karyawan diharapkan menunjukan presisi, analisis, dan perhatian pada hal-hal yang detail.

3. Outcome orientation (Berorientasi kepada hasil). Yakni sejauh mana pimpinan berfokus pada hasil bukan pada taknis dari proses yang dipakai untuk menjadi hash.

4. People orientation (Berorientasi manusia). Yakni sejauh mana keputusan manajemen memperhatikan efek hasil - hasil pada orang dalam model perilaku diatas menjadi inti dari suatu budaya

5. Team orientation (Berorientasi tim). Yakni sejauh mana kegiatan kerja di organisasikan atas dasar tim kerja dari pada individu

6. Aggressiveness (Agresif). Yakni sejauh mana orang - orang bersifat agresif dan kompetitif bukan santai santai

7. Stability (Stabilitas). Yakni sejauh mana aktifitas organisasi menekankan 
pemeliharaan status quo, sebagai kontras dari pertumbuhan.

\section{Kerangka Pemikiran}

\begin{tabular}{|c|c|}
\hline \begin{tabular}{|l}
\multicolumn{2}{|l}{ Budaya Organisasi } \\
(Variable X)Indikator \\
- Inovatif dan mengambil \\
resiko \\
- Perhatian kepada detail \\
- Orientasi hasil \\
- Orientasi manusia \\
- Orientasi tim \\
- Agresif \\
- stabilitas \\
Menurut O'reily dan Jehn \\
(Deddy Mulyadi, 2015:121)
\end{tabular} & \begin{tabular}{ll} 
& \multicolumn{1}{c}{ Kinerja } \\
- & Muriable Y)Indikator \\
- & Kejujuran karyawan \\
- & Inisiatif \\
- & Kehadiran \\
- & Sikap \\
- & Kerjasama \\
- & Keandalan \\
- & Pengetahuan tentang \\
- & Takerjaan \\
- & Pemangung jawab \\
Menurut Husen Uman $(2001: 266)$
\end{tabular} \\
\hline
\end{tabular}

Sumber: Aput Ivan Aliandra (2015)

Gambar 1. Kerangka Pemikiran

\section{METODE PENELITIAN}

Metode penelitian yang di gunakan pada penelitian ini adalah metode deskriptif dengan pendekatan kuantitatif, menurut Sugiyono (2008:147) metode deskriptif adalah statistik yang digunakan untuk menganalisis data dengan cara mendeskripsikan atau menggambarkan data yang telah terkumpul sebagaimana adanya tanpa bermaksud membuat kesimpulan yang berlaku untuk umum atau generalisasi. Berdasarkan pengertian tersebut, maka dapat disimpulkan metode deskriptif bertujuan menggambarkan benar tidaknya fakta - fakta yang ada serta menjelaskan tentang pengaruh antara varibel yang diselidiki dengan cara mengumpulkan data.

\section{Populasi dan Sampel}

Menrut sugiono (2008:115-116) Populasi adalah wilayah generalisasi yang terdiri atas objek atau subjek yang mempunyai kualitas dan karakteristik tertentu yang di tetapkan oleh peneliti untuk dipelajari dan kemudian ditarik kesimpulannya.

Dalam penelitian ini yang menjadi sampel adalah seluruh populasi atau seluruh karyawan yang ada pada PT. PLN (Persero) Area Bandung mengingat jumlah populasi kurang dari 100 .

Sedangkan yang dimaksud sampel adalah bagian daripopulasi yang menjadi sumber data yang sebenarnya. Seperti yang dikemukakan oleh Sugiyono (2012:81) sampel adalah bagian dari jumlah dan karakteristik yang dimiliki oleh populasi tersebut. Pengambilan sebagian itu di maksudkan sebagai respresentasi dari seluruh populasi sehingga kesimpulan juga berlaku kepada keseluruhan populasi. Adapun rumus sederhana untuk penentuan ukuran sampel menurut Husein Umar (2007:78) dengan menggunakan rumus slovin sebagai berikut:

$$
n=\frac{N}{1+N e^{2}}
$$


Keterangan :

$\mathrm{n}=$ Jumlah sampel

$\mathrm{N}=$ BesarPopulasi

$\mathrm{e}=$ Tingkat Kepercayaan $(10 \%=0.01)$

Suharsimi Arikunto (2002:112)

berpendapat bahwa apabila subjek kurang

dari 100, maka lebih baik di ambil semua.

Sedangkan jika subjeknya besar melebihi 100 maka dapat di ambil antara 10\%-15\% atau $20 \%-25 \%$ atau lebih. Mengingat jumlah populasi kurang dari 100, untuk mendapatkan data yang mewakili maka dalam penelitian ini seluruh populasi bagian administrasi umum di PT.PLN (Persero) Area Bandung Jl. Soekarno Hatta, Bandung No.436 yaitu 40 orang karyawan dijadikan respoden penelitian.

\section{Teknik Uji Validitas dan Reliabilitas Uji Validitas}

Sugiyono (2008:172) Menyatakan bahwa instrument yang valid berarti alat ukur yang digunakan untuk mendapatkan data (mengukur) itu valid. Valid berarti instrument tersebut dapat digunakan untuk mengukur apa yang seharusnya di ukur. Meteran yang valid dapat di gunakan untuk mengukur panjang dengan teliti.

Instrument yang validasi internal atau rasional, bila kriteria yang ada dalam instrument secara rasional (teoritids) telah mencerminkan apa yang diukur. Jadi kriterianya ada di dalam instrument itu. Oleh karena itu peneliti harus mampu mengendalikan objek yang diteliti dan meningkatkan kemampuan dan menggunakan instrument untuk mengukur variable

Sugiyono (2008:179) menguraikan pengujian validitas tiap butir digunakan analisis item, yaitu menggunakan korelasi skor tiap butir dengan skor total yang merupakan jumlah tiap skor butir. Dalam hal analisis item ini, Masrun, (Sugiyono, 2008:179) menyatakan analysis untuk mengetahui daya pembeda, sering juga dinamakan analisis untuk mengetahui validitas item.
Ukuran terkait antara butir pertanyaan ini umumnya di cerminkan oleh korelasi rendah dengan butir pertanyaan lain, dinyatakan tidak valid. Metode yang digunakan untuk memberikan penilaian terhadap validitas kuesioner adalah korelasi produk momen (momen product correlation).

Menurut Sugiyono nilai korelasi (r) produk momen dihitung dengan rumus sebagai berikut;

$$
r=\frac{\left(n \sum X Y\right)-\left(\sum X\right)\left(\sum Y\right)}{\sqrt{\left\{\left(n \sum X^{2}\right)-\left(\sum X\right)^{2}\right\}\left\{\left(n \sum Y^{2}\right)-(\right.}}
$$

Sumber: riduwan, (

$$
\text { 2012:98) }
$$

Keterangan :

$\mathrm{r}=$ Koefisien korelasi item yang dicari

$\mathrm{X}=$ Skor item yang di peroleh subjek dalam setiap item

$\mathrm{Y}=$ Skor total yang diperoleh subjek dalam seluruh item

$\mathrm{n}=$ Jumlah Respondem uji coba

Biasanya dalam pengembangan dan penyusunan skala - skala psikologi, di gunakan harga koefisien yang minimal sama dengan 0,30 dengan demikian, semua item yang memiliki korelasi kurang dari 0,30 dapat disisihkan dan item - item yang dimasukan dalam alat test adalah item - item yang memiliki korelasi diatas 0,30 dengan pengertian semakin tinggi korelasi itu mendekati angka satu $(1,00)$ maka semakin baik pula konsistensinya (validitasnya).

\section{Uji Reliabilitas}

Menurut Sugiyono, (2008:172-173) menyatakan bahwa reliabilitas berarti instrument yang bila digunakan beberapa kali untuk mengukur objek yang sama akan menghasilkan data sama. Suharsimi Arikunto menyatakan Reabilitas menunjukan pada suatu pengertian bahwa suatu instrument cukup dapat dipercaya untuk di gunakan sebagai alat 
pengumpulan data karena instrument tersebut sudah baik.

Uji reliabilitas dilakukan dengan menggunakan metode alpha cronbach's yang di rumuskan urbina sebagai berikut.

$$
r_{11}=\left[\frac{k}{k-1}\right]\left[1-\frac{\sum S_{i}^{2}}{S_{t}^{2}}\right]
$$

Sumber : Riduwan (2012:108)

Keterangan:

$r_{11}=$ reliabilitas instrument

$k$ = banyaknya bulir soal

$\sum S_{i}^{2}=$ varians total

Sugiyono (2011:356) menyatakan bahwa reliabilitas suatu kondtruktur dinyatakan baik apabila memiliki nilai alpha crobach's lebih besar dari 0,60 jadi pengujian rehabilitas instrument dalam suatu penelitian dilakukan karena keterandalan instrument berkaitan dengan taraf kepercayaan terhadap instrument penelitian tersebut

\section{Transformasi Data}

Pengumpulan data melalui kuesioner dengan penilaian jawaban angket five option scale, menghasilkan data dengan skala ordinal. Oleh karena itu peneliti harus mentransformasikan data dengan skala ordinal ke Skala Interval untuk memenuhi persyaratan analisis regresi (data harus bersifat interval atau rasio), maka data dalam bentuk skala ordinal tersebut harus ditingkatkan menjadi skala interval.

Peningkatan skala ordinal menjadi interval dalam penelitian ini akan digunakan Method of Successive Intervals (MSI). Dalam MSI, peningkatan skala dari ordinal ke interval ini dilakukan untuk setiap item pada masing-masing variabel.

Tahapan-tahapan Metode of Successive Interval adalah sebagai berikut:

1. Menentukan frekuensi setiap responden.
2. Menentukan proporsi setiap responden dengan membagi frekuensi dengan jumlah sampel.

3. Menjumlahkan proporsi secara berurutan untuk setiap respon sehingga diperoleh kumulatif.

4. Menentukan nilai $\mathrm{Z}$ untuk masingmasing proporsi kumulatif yang dianggap menyebar mengikuti sebaran normal baku.

5. Menghitung scale value (SV) terkecil menjadi sama dengan satu (1) dan mentransformasikan masing-masing skala menurut perubahan skala terkecil sehingga diperoleh transformes scale value (TSV).

\section{Teknik Analisis Data}

Analisa data adalah suatu proses penyederhanaan data ke dalam bentuk yang lebih mudah dibaca dan diinterprestasikan. pengolahan data hasil survey dilakukan dengan menggunakan program Statistik dan SPSS. Berikut ini adalah teknik - teknik analisis data yang digunakan dalam penelitian.

\section{Uji Normalitas}

Menurut sugiyono (2008:295), statistik parametris mensyaratkan bahwa setiap variabel yang akan dianalisis harus berdistribusi normal maka sebelum pengujian hipotesis dilakukan terlebih dahulu pengujian normalitas data pengujian normalitas dilakukan pada kedua variabel yang diteliti, variabel bebas (X) budaya organisasi dan variabel terikat (Y) kinerja karyawan. Rumus yang digunakan adalah rumus KolmogorovSmirnov. Kelebihan dari KolmogorovSmirnov adalah sederhana dan tidak menimbulkan perbedaan persepsi dari satu pengamatan dengan pengamatan yang lain. uji normalitas ini dianalisis menggunakan bantuan komputer program SPSS versi 22 kaidah yang digunakan untuk mengetahui normal tidaknya suatu sebaran adalah: 
$p>0,05$ dinyatakan normal, $p<0,05$ dinyatakan tidak normal.

\section{Analisis Korelasi}

Menurut Sugiyono (2012:183) teknik korelasi ini digunakan untuk mencari hubungan dan membuktikan hipotesis hubungannya variabel bila data dari dua variabel atau lebih tersebut adalah sama. Untuk Analisis Korelasi peneliti menggunakan Korelasi Pearson Product Moment untuk mencari kekuatan hubungan variabel bebas (X) dan variabel terikat (Y), dan data berbentuk interval.

Koefisien korelasi (r) menunjukan derajat kolerasi antara $\mathrm{x}$ dan $\mathrm{y}$ analisis ini digunakan untuk melihat kekuatan hubungan dari dua variabel. kedua variabel tersebut merupakan variabel pokok, yaitu variabel terikat dan variabel tidak terikat.

Koefisien korelasi (KK) memiliki nilai antara -1 dan $+1(-1 \leq \mathrm{KK} \leq+1)$

a. Jika KK bernilai positif maka variabel - variabel berkorelasi positif. Semakin dekat nilai $\mathrm{KK}$ ke +1 semakin kuat korelarinya, demikian pula sebaliknya.

b. Jika KK bernilai negatif maka variabel - variabel berkolerasi negatif. Semakin dekat nilai KK ke -1 semakin kuat kolerasinya, demikian pula sebaiknya.

c. Jika KK bernilai 0 (nol) Maka variabel - variabel tidak menunjukan korelasi.

d. Jika KK bernilai +1 atau -1 maka variabel - variabel menunjukan korelasi positif atau negative yang sempurna.

\section{Analisis Regresi Linier Sederhana}

Analisis Regresi adalah suatu analisis yang di gunakan untuk mencari hubungan antara dua variabel atau lebih, sehingga dapat memprediksikan suatu variabel apabila variabel lain diketahui. Dalam penelitian ini analisis regresi digunakan untuk mengetahui apakah terdapat pengaruh antara budaya organisasi terhadap kinerja karyawan.

Persamaan regresi yang digunakan adalah persamaan regresi linear sederhana karena hanya meneliti dua variable saja yaitu budaya organisasi sebagai variabel independent (X) dan kinerja karyawan sebagai variabel dependent (Y), maka bentuk persamaannya menurut sugiyono (2008:270) adalah sebagai berikut:

$$
Y=a+b X
$$

Sumber : Sugiyono (2008:270)

Keterangan :

$\mathrm{X}=$ Subjek variabel independent yang mempunyai nilai tertentu

$\mathrm{Y}=$ Subjek variabel dependent yang di prediksi

$\mathrm{a}=$ Harga $\mathrm{Y}$ jika $\mathrm{X}$ sama dengan nol (harga konstan)

$\mathrm{b}=$ koefisien yang menunjukan angka peningkatan $(b+)$ atau penurunan (b-) variabel dependen yang di dasarkan pada variabel independen.

$\mathrm{X}$ dikatakan mempengaruhi $\mathrm{Y}$, jika perubahan nilai $X$ dapat menyebabkan adanya perubahan pada nilai $\mathrm{Y}$ atau dengan kata lain naik turunnya nilai $X$ akan membuat naik turun nilai $\mathrm{Y}$ juga. Namun perubahan nilai $\mathrm{Y}$ bukan hanya karena disebabkan oleh $\mathrm{X}$ saja akan tetapi banyak faktor lain yang dapat menyebabkannya.

\section{Koefisien Determinasi}

Untuk mengetahui besarnya pengaruh budaya organisasi (variabel $\mathrm{X}$ ) terhadap kinerja karyawan (variabel Y), maka digunakan koefisien determinasi dengan rumus:

Keterangan:

$$
k d=r s^{2} \times 100 \%
$$

$k d=$ koefisien determinasi

$r s=$ koefisien korelasi

\section{Teknik Pengujian Hipotesis}

Untuk menentukan hubungan antar variabel maka dilakukan pengunjian 
hipotesis. Langkah - langkah sebagai berikut:

1. Menentukan $\mathrm{H}_{\mathrm{o}}$ dan $\mathrm{H}_{\mathrm{i}}$

a. $\mathrm{H}_{\mathrm{o}}: \mathrm{r}_{\mathrm{s}} \leq 0$ : menunjukan tidak terdapat pengaruh yang signifikan antara budaya organisasi dengan kinerja karyawan.

b. $\mathrm{H}_{\mathrm{i}}: \mathrm{r}_{\mathrm{s}} \geq 0$ : menunjukan terdapat pengaruh yang signifikan antara budaya organisasi terhadap kinerja karyawan.

2. Menentukan $T_{\text {tabel }}$ Interval keyakinan sebesar $95 \%$, sehingga tingkat kesalahan/taraf signifikan $\left({ }^{a}\right)$ sebesar 5\% $(0,05)$ dan derajat kebebasan $(\mathrm{dk})=\mathrm{n}^{-2}$

3. Menentukan $\mathrm{T}_{\text {hitung }}$ rumus :

$$
t=\sqrt[r_{s}]{\frac{N-2}{1-r_{s}^{2}}}
$$

Sumber : Riduwan (2012:98)

Keterangan :

$t=$ Distribusi nilai $\mathrm{t}$ hitung student dengan derajat kebebasan $\mathrm{dk}=\mathrm{n}-2$

$r_{s}=$ Koefisien korelasi hasil $\mathrm{r}$ hitung

$N=$ Jumlah responden

4. Membandingkan antara $\mathrm{T}_{\text {hitung }}$ dengan $\mathrm{T}_{\text {tabel }}$

a. Jika $\mathrm{T}_{\text {hitung }} \geq \mathrm{T}_{\text {tabel }}$ maka $\mathrm{H}_{\mathrm{o}}$ ditolak dan $\mathrm{H}_{\mathrm{i}}$ diterima, berarti terdapat pengaruh antara variabel $\mathrm{X}$ dengan variabel $\mathrm{Y}$.

Jika $T_{\text {hitung }} \leq \mathrm{T}_{\text {tabel }}$ maka $\mathrm{H}_{\mathrm{o}}$ diterima dan $\mathrm{H}_{\mathrm{i}}$ ditolak, berarti tidak terdapat pengaruh antara variabel $\mathrm{X}$ dengan variabel $\mathrm{Y}$.

\section{Identitas Responden}

- 40 responden, 16 orang kayawannya $(40 \%)$ berjenis kelamin laki-laki, dan 24 karyawannya berjenis kelamin perempuan $(60 \%)$ dengan demikian jenis kelamin responden di dominasi oleh perempuan yang berjumlah 24 orang $(60 \%)$.
- karyawan dengan rentang usia antara 21-25 tahun berjumlah 7 orang (17,5\%), usia 26-30 tahun berjumlah 9 orang (22,5\%), rentang usia 31-35 tahun sebanyak 11 orang $(27,5 \%)$, dan rentang usia >35 tahun sebanyak 13 orang yaitu $(32,5 \%)$ dengan demikian pengelompokan usia di dominasi oleh rentang usia >35 tahun sebanyak 13 orang $(32,5 \%)$.

- responden pendidikan SMA/ sederajat sebanyak 6 orang (15\%), sedangkan tingkat pendidikan Diploma sebanyak 22 orang (55\%), dan tingkat pendidikan Sarjana sebanyak 12 orang $(30 \%)$.

- responden dengan masa kerja $\leq 5$ tahun sebanyak 7 orang (17,5), 6-10 tahun sebanyak 14 orang (35\%), 11-15 tahun sebanyak 10 orang (25\%), 16-20 tahun sebanyak 6 orang (15\%), dan $>20$ tahun sebanyak 3 orang $(7,5 \%)$.

\section{Validitas dan Reliabilitas}

Berdasarkan tabel 4.4 hasil uji validitas dan uji reliabilitas butir variabel Budaya Organisasi dan butir variabel Kinerja Karyawan di atas menunjukan bahwa terdapat tiga butir pernyataan dinyatakan tidak valid yaitu pada pertanyaan pernyataan nomor Y8,Y12, dan Y15 sehingga butir - butir pertanyaan pernyataan yang tidak valid akan dikeluarkan dari analisis selanjutnya karena memiliki nilai validitas kurang dari 0,30 validitas dinyatakan valid apabila nilai butir tersebut lebih besar dari 0,30 sedangkan uji reliabilitas dinyatakan reliable karena baik variabel $\mathrm{X}$ budaya organisasi maupun variabel $\mathrm{Y}$ kinerja karyawan memiliki nilai lebih besar dari 0,60 .

\section{Hasil Analisis Data}

Analisis data untuk menguji hipotesis beberapa uji persyaratan yang harus terpenuhi agar hasilnya dapat dipertanggung jawabkan. Uji persyaratan analisis meliputi: 


\section{Uji Normalitas}

Tujuan uji normalitas adalah untuk mengetahui apakah data yang diperoleh dari tiap-tiap variabel yang dianalisis sebenarnya mengikuti pola sebaran normal tau tidak, lalu pengujian normalitas variabel dilakukan dengan menggunakan Kolmogorov-Smirnov, kaidah yang digunakan untuk mengetahui normal tidaknya suatu sebaran adalah $p>$ 0,05 sebaran dinyatakan normal, dan jika $p<0,05$ sebaran tidak dikatakan normal, dapat di lihat dari tabel 4.38 dibawah ini:

Tabel 3.Uji Normalitas

Tests of Normality

\begin{tabular}{|l|r|r|r|r|r|r|}
\hline & \multicolumn{3}{|c|}{ Kolmogorov-Smirnov $^{\mathrm{a}}$} & \multicolumn{3}{c|}{ Shapiro-Wilk } \\
\cline { 2 - 7 } & Statistic & \multicolumn{1}{c|}{ Df } & \multicolumn{1}{c|}{ Sig. } & Statistic & \multicolumn{1}{c|}{ Df } & \multicolumn{1}{c|}{ Sig. } \\
\hline Budaya & .124 & 40 & .123 & .949 & 40 & .069 \\
Organisasi & .136 & 40 & .062 & .955 & 40 & .116 \\
Kinerja Karyawan & & & & & \\
\hline
\end{tabular}

a. Lilliefors Significance Correction

sumber: data diolah menggunakan spss versi 22, 2016

Berdasarkan tabel di atas dapat dilihat bahwa nilai probabilitas variabel budaya organisasi (X) pada kolom Sig sebesar 0,123 sedangkan untuk variabel kinerja karyawan (Y) pada kolom Sig sebesar 0.062 yang artinya nilai probabilitas tersebut bersifat normal, karena nilai probabilitas dari kedua variabel lebih dari 0,05 .

\section{Uji Korelasi}

uji korelasi dalam penelitian ini menggunakan korelasi product moment untuk mencari kekuatan hubungan antara variabel $\mathrm{X}$ dan Variabel $\mathrm{Y}$ Hasil uji korelasi antara Variabel Budaya Organisasi dengan Kinerja Karyawan dapat dilihat dalam table di bawah ini:

Tabel 4.Analisa Korelasi

\begin{tabular}{|ll|r|r|}
\hline & \multicolumn{1}{c|}{$\begin{array}{c}\text { Budaya } \\
\text { Organisasi }\end{array}$} & $\begin{array}{c}\text { Kinerja } \\
\text { Karyawan }\end{array}$ \\
\hline Budaya & Pearson & 1 & $.770^{* *}$ \\
Organisasi & Correlation & & .000 \\
& Sig. (2-tailed) & 40 & 40 \\
\hline Kinerja & Pearson & $.770^{* *}$ & 1 \\
Karyawan & Correlation & .000 & \\
& Sig. (2-tailed) & 40 & 40 \\
& $\mathrm{~N}$ & & 1 \\
\end{tabular}

Sumber: data diolah menggunakan spss versi 22, 2016

Berdasarkan table di atas maka dapat dilihat bahwa koefisien korelasi product momen pearson antara budaya organisasi dengan kinerja karyawan adalah sebesar +770 dan dapat disimpulkan bahwa angka koefisien tersebut menunjukan adanya 
korelasi yang kuat antara budaya organisasi dengan kinerja karyawan yaitu sebesar 0,770 sedangkan tanda "+" menunjukan bahwa arah hubungan positif.

\section{Uji Regresi Linier Sederhana}

Analisis regresi analisis ini digunakan untuk mendapatkan hubungan antara dua variabel atau lebih, persamaan regresi yang akan digunakan adalah regresi linear sederhana. Bentuk umum regresi linear sederhana adalah sebagai berikut : $\mathbf{Y}=\mathbf{a}+\mathbf{b X}$
Dimana $: Y=$ Variabel dependent $($ kinerja karyawan )

$$
\begin{aligned}
& \mathrm{a}=\text { Nilai konstanta } \\
& \mathrm{b}=\text { Koefisien regresi } \\
& \mathrm{X}=\text { Variabel independent }
\end{aligned}
$$

(budaya organisasi)

Berdasarkan hasil perhitungan program IBM Stastitical for Product and Service Solution (SPSS) versi 22. Didapat hasil dari regresi linear sederhana sebagai berikut :

\begin{tabular}{|c|c|c|c|c|c|c|}
\hline \multirow{2}{*}{\multicolumn{2}{|c|}{ Model }} & \multicolumn{2}{|c|}{$\begin{array}{c}\text { Unstandardized } \\
\text { Coefficients }\end{array}$} & \multirow{2}{*}{$\begin{array}{c}\text { Standardized } \\
\text { Coefficients } \\
\text { Beta }\end{array}$} & \multirow[b]{2}{*}{$\mathrm{T}$} & \multirow[b]{2}{*}{ Sig. } \\
\hline & & B & Std. Error & & & \\
\hline 1 & (Constant) & 5.037 & 4.986 & & 1.010 & .319 \\
\hline & $\begin{array}{l}\text { Budaya } \\
\text { Organisasi }\end{array}$ & .830 & .112 & .770 & 7.428 & .000 \\
\hline
\end{tabular}

\section{Tabel 5.Analisa Regresi} Coefficients $^{\mathrm{a}}$

a. Dependent Variable: Kinerja Karyawan sumber: data diolah menggunakan spss versi 22, 2016

Berdasarkan tabel 4.40 nilai Constant(a) adalah 5.037 sedangkan nilai $\mathrm{X}$ (b) adalah 0,830 sehingga persamaan regresinya dapat ditulis

$$
\mathbf{Y}=\mathbf{a}+\mathbf{b X} \text { atau } 5,037+\mathbf{0 , 8 3 0 X}
$$

Dimana $: Y=$ Variabel dependent $($ Kinerja karyawan )

$$
\begin{aligned}
& a=\text { Nilai konstanta } \\
& b=\text { Koefisien regresi } \\
& X=\text { Variabel independent }
\end{aligned}
$$

(budaya organisasi)

Hasil Konstanta sebesar 5,037 menyatakan bahwa jika tidak ada nilai trust $(\mathrm{X})$ maka nilai partisipasi sebesar 5,037. Koefisien regresi $X$ sebesar 0,830 menyatakan bahwa setiap penambahan 1 nilai trust (x) maka nilai pasrtisipasi bertambah 0,830 artinya jika budaya organisasi mengalami peningkatan maka kinerja karyawan akan mengalami peningkatan sebesar $83,0 \%$.

\section{Koefesien determinasi}

Untuk mengetahui persentasi pengaruh variabel independen (kualitas produk) terhadap variabel dependen (Loyalitas Pelanggan), dihitung dengan uji koefisien determinasi. Berikut tabel hasil penghitungan program IBM Stastitical for Product and Service Solution (SPSS) versi 22.

Tabel 6.Koefesien Determinasi
Model Summary
\begin{tabular}{|l|c|r|r|r|}
\hline & & & & $\begin{array}{c}\text { Std. } \\
\text { Error of } \\
\text { the } \\
\text { Model }\end{array}$ \\
& $\mathrm{R}$ & $\begin{array}{c}\mathrm{R} \\
\text { Square }\end{array}$ & $\begin{array}{c}\text { Adjusted } \\
\text { R Square }\end{array}$ & Estimate \\
\hline 1 & $.770^{\mathrm{a}}$ & .592 & .581 & 5.156 \\
\hline
\end{tabular}

a. Predictors: (Constant), Budaya Organisasi 
Sumber: data diolah menggunakan spss versi Ŗ̧i Hipotesis

2016

Tabel di atas menjelaskan bahwa besarnya nilai korelasi sebesar 0,592 dan dijelaskan besarnya presentasi pengaruh Variabel Independen terhadap Variabel Dependen. Dari output tersebut diperoleh Koefisien Determinasi (R2) sebesar $59,2 \%$ sedangkan sisanya $40,8 \%$ dipengaruhi oleh variabel lain.
Pengujian ini membuktikan Ho atau $\mathrm{Hi}$ yang akan diterima. Jika $\mathrm{Hi}$ diterima maka Ho di tolak dan sebaliknya, untuk melihat ada atau tidak nya pengaruh antara varibel $\mathrm{X}$ (budaya organisasi) dan Variabel Y (kinerja karyawan). Dapat dilihat pada tabel 4.42, jika nilai propabillity $\mathrm{t}<0,05$ maka Ha diterima, sedangkan jika nilai probability $\mathrm{t}>0,05$ maka Ha ditolak.

Tabel 7.Uji Statistik $\mathbf{t}$

Coefficients $^{\mathrm{a}}$

\begin{tabular}{|c|c|c|c|c|c|}
\hline \multirow[b]{2}{*}{ Model } & \multicolumn{2}{|c|}{$\begin{array}{l}\text { Unstandardized } \\
\text { Coefficients }\end{array}$} & $\begin{array}{c}\text { Standardize } \\
\mathrm{d} \\
\text { Coefficient } \\
\mathrm{s} \\
\end{array}$ & \multirow[b]{2}{*}{$\mathrm{T}$} & \multirow[b]{2}{*}{ Sig. } \\
\hline & $\mathrm{B}$ & Std. Error & Beta & & \\
\hline $1 \quad$ (Constant) & 5.037 & 4.986 & & 1.010 & .319 \\
\hline $\begin{array}{l}\text { Budaya } \\
\text { Organisasi }\end{array}$ & .830 & .112 & .770 & 7.428 & .000 \\
\hline
\end{tabular}

a. Dependent Variable: Kinerja Karyawan

Sumber: data diolah menggunakan spss versi 22, 2016

Berikut hasil Uji Signifikansi berdasarkan tabel di atas :

1. Membuat hipotesis dalam urain kalimat :

Ho = Tidak terdapat pengaruh signifikan budaya organisasi terhadap kinerja karyawan

$\mathrm{Ha}=$ Terdapat pengaruh signifikan budaya organisasi terhadap kinerja karyawan

2. Menentukan $t_{\text {tabel }}$ dan $t_{\text {hitung }}$ $\mathrm{t}$ hitung dapat di lihat pada tabel 4.42 yaitu sebesar 7,428 sedangkan $t$ tabel sebesar 1,686 dapat dilihat pada lampiran $t$ tabel.

3. Membandingkan $\mathrm{t}$ tabel dan $\mathrm{t}$ hitung

$t_{\text {hitung }}: 7,428$

$\mathrm{t}$ tabel $: 1,686$

$\mathrm{t}_{\text {hitung }} \geq \mathrm{t}_{\text {tabel }}$
Maka dapat diambil keputusan menerima dan menolak $\mathrm{H}_{\mathrm{o}} \mathrm{t}$ hitung $\geq \mathrm{t}_{\text {tabel }}$, maka $\mathrm{H}_{\mathrm{o}}$ ditolak dapat dilihat bahwa 7,428 $\geq 1,686$ artinya $\mathrm{H}_{\mathrm{o}}$ ditolak dan $\mathrm{H}_{\mathrm{i}}$ diterima, kesimpulan yang dapat diambil yaitu terdapat pengaruh yang signifikan budaya organisasi terhadap kinerja karyawan.

\section{SIMPULAN DAN SARAN}

Budaya organisasi pada bagian administrasi umum di PT PLN (Persero) Area Bandung secara umum dipersepsikan baik dan mendukung, hal itu bisa di lihat dari hasil rekapitulasi masing-masing item dari 7 indikator meski masih ada beberapa item memiliki nilai terendah, item tersebut terdapat pada indikator orientasi tim dan indikator perhatian terhadap detail.

Kinerja karyawan pada bagian administrasi umum di PT PLN (Persero) 
Area Bandung secara umum dipersepsikan baik dan mendukung, hal itu bisa di lihat dari hasil rekapitulasi masing-masing item dari 10 indikator meski masih ada item memiliki nilai terendah sehingga item tersebut terdapat pada indikator Pemanfaatan waktu.

Hasil analisis variabel budaya organisasi dengan variabel kinerja karyawan menunjukan bahwa adanya pengaruh yang positif sehingga dapat meningkatkan kinerja karyawan, begitu juga sebaliknya, secara keseluruhan budaya organisais dan kinerja karyawan berada dalam kriteria baik, hal itu terbukti adanya pengaruh yang signifikan yaitu sebesar 59,2\% variabel budaya organisasi mempengaruhi variabel kinerja karyawan sedangkan $40,8 \%$ dipengaruhi oleh variabel lain yang tidak dikaji dalam penelitian ini.

Budaya organisasi terhadap kinerja karyawan pada bagian Administrasi Umum PT PLN (Persero) Area Bandung sudah baik namun perusahaan harus lebih memperhatikan dan memperkuat kembali budaya organisasi yang ada sehingga para pelaku organisasi merasa nyaman dan dapat mempengaruhi karyawan dalam meningkatkan kinerjanya. Hendaknya setiap karyawan mampu bersikap dan mampu menciptakan lingkungan kerja yang harmonis, khususnya suasana kerja antar karyawan ditingkatkan agar dapat mempertahankan kenyamanan dalam berorganisasi.

\section{DAFTAR PUSTAKA}

Anwar, Prabu, Mangkunegara. (2014). Evaluasi Kinerja SDM. Bandung: PT Refika Aditama.

Ahmad, S, Ruky. (2002). Paradigma Baru Manajemen Sumber Daya Manusia. Yogyakarta: Penerbit Amara Books.

Alianda, Ivan, Aput. (2015). Analisis Pengaruh Budaya Organisasi Terhadap Kinerja Karyawan Depok Sport Center. Yogyakarta: Universitas Negri Yogyakarta.
Deddy, Mulyadi. (2015). Perilaku Organisasi dan Kepemimpinan Pelayanan. Bandung: Alfabeta, cv.

Deddy, Mulyadi, dan Jalaluddin, Rakhmat. (2010). Komunikasi Antar Budaya. Bandung: Pt Remaja Rosdakarya

Husen, Umar. (2001). Manajemen Sumber Daya Manusia Dalam Organisasi. Edisi Revisi Dan Perluasan, Jakarta: Gramedia Pustaka Utama

Husen, Umar. (2007). Metode Penelitian Untuk Skripsi dan Tesis Bisnis. Jakarta: Pt Raja Grapindo Persada.

Irham, Fahmi. (2013). Manajemen Kinerja Teori dan Aplikasi, Bandung: Alfabeta,cv

Kusdi. (2011). Budaya Organisasi. Jakarta: Salemba Empat.

Lijan, Poltak, Sinambela. (2012). Kinerja Pegawai (Teori Pengukuran dan Implikasi), Yogyakarta: Graha Ilmu.

Miftah, Thoha. (2007). Perilaku Organisasi, Konsep Dasar dan Aplikasinya, Jakarta: PT. Raja Grafindo Persada.

Moeldjono, Djokosantoso, Sudjatmiko, Steven. (2007). Corporate Culture: Challenge To Excellence, Jakarta: PT. Elex Media Komputindo.

Moh. Pabundu, Tika. (2010). Budaya Organisasi Dan Peningkatan Kinerja Karyawan. Jakarta: Pt. Bumi Aksara.

Moh. Pabundu, Tika. (2012). Budaya Organisasi Dan Kinerja Perusahaan. Bandung: Pt. Bumi Aksara

Nurhayati. (2014). Pengaruh Pemanfaatan Teknologi Informasi Terhadap Laporan Keuangan Di Rumah Sakit Muhammadiyah Bandung. Bandung: Sekolah Tinggi Ilmu Ekonomi Muhammadiyah Bandung.

Riani. Asri, Laksmi. (2011). Budaya Organisasi. yogyakarta: Graha Ilmu

Riduwan. (2012). Belajar Mudah Penelitian Untuk Guru-Karyawan 
dan Peneliti Pemula. Bandung: Suharsimi, Arikunto. (2002). Prosedur Alfabeta, cv Penelitian Suatu Pendekatan Praktek. Jakarta: PT. Rineka Cipta.

Sugiyono. (2008). Metode Penelitian Bisnis. Bandung: Alfabeta, cv.

Sutarto. (2006). Dasar - Dasar Organisasi. Yogyakarta: Gajah Mada University Press

Sugiyono. (2012). Metode Penelitian Kuantitatif Kualitatif Dan $R \& D$. Bandung: Alfabeta, cv.

Sugiyono. (2011). Metode Penelitian Kuantitatif Kualitatif Dan $R \& D$. Bandung: Alfabeta, cv.

Sugiyono. (2013). Metode Penelitian Bisnis. Bandung: Alfabeta, cv.

Sugiyono. (2014). Metode Penelitian Administrasi Dilengkapi Dengan Metode $R \& D$. Bandung: Alfabeta, cv.

Sobirin, Achmad. (2007). Budaya Organisasi. Yogyakarta: STIMB YKPN.

Suwanto, dan Donni, Juni, Priansa. (2011). Manajemen SDM Dalam Organisasi Publik dan Bisnis, Bandung: Alfabeta,cv.

Taliziduhu, Ndraha. (2005). Teori Budaya Organisasi, Jakarta: PT Rineka Cipta.

Wibowo. (2007). Manajemen Kinerja. Jakarta: Rajawali Pers.

Wibowo. (2011). Manajemen Kinerja. Jakarta: Rajawali Pers. 